\title{
IMPLANT SUPPORTED MANDIBULAR OVERDENTURES WITH LOCATOR ATTACHMENTS IN PATIENTS WITH RESORBED MANDIBULAR RIDGES. A CROSS OVER STUDY OF PATIENT SATISFACTION AND ORAL HEALTH RELATED QUALITY OF LIFE
}

\author{
Shahinaz Sayed Mohamed Hassan * and Mohamad Hossam El-Din Helmy**
}

\begin{abstract}
Purpose: The aim of this cross over study was evaluation of patient satisfaction and oral health related quality of life (OHRQoL) for implant supported mandibular overdentures with locator attachments in patients with resorbed ridges

Materials and methods: Six participants ( 3 males and 3 females) with total maxillary and mandibular edentulism who complained from lack of retention of old mandibular dentures due to ridge resorption received new conventional dentures. After 3 months adaptation period, 4 implants were inserted between the 2 mental foramina of the mandible using one stage non submerged delayed loading approach. After 3 months of integration period, dentures were connected to the implants with Locator attachments. Patient satisfaction was measured using patient satisfaction questionnaires and oral health related quality of life was measured using oral health impact profile (OHIP-14). Measurements were made after 3 months of using conventional dentures (control group) and implant overdentures (study group).
\end{abstract}

Results: Regarding VAS questionnaires, test group showed significant higher general satisfaction, satisfaction compared to natural teeth, satisfaction with retention, stability, occlusion, speech, mastication, prosthesis is a part of patient, and lack of embarrassment compared to control group. Regarding OHIP-14, test group showed significant less pain and more comfort on eating, less self-consciousness, and less sensation of tense, more satisfaction with food and less interruption of meal, more ability to relax and less embarrassing, less irritation with other and more satisfaction with life generally and less difficulty in function well than control group

Conclusion: Implant supported mandibular overdentures with locator attachments are recommended for patients with atrophied mandibular ridges as they significantly improve patient satisfaction and quality of life compared to conventional dentures.

KEYWORDS: Implant, overdentures, Locator, patients satisfaction, OHRQoL

* Lecturer, Department of Removable Prosthodontics, Faculty of Dentistry, Beni-Suef University, Egypt.

** Lecturer, Department of Removable Prosthodontics, Faculty of Dentistry, Assiut University, Assiut, Egypt. 


\section{INTRODUCTION}

Edentulism is a poor health condition that may compromise patient satisfaction and quality of life ${ }^{1}$. Resorbed mandible show a significant challenge in case of rehabilitation with oral implants ${ }^{2}$. The atrophic mandible has low load-bearing ability and when conventional denture were constructed, pain during mastication, insufficient stability and retention of the mandibular usually results ${ }^{3}$ and may further precipitate in psychosocial problems to the patients ${ }^{4,5}$

Although ridge augmentation can restore adequate ridge contour, bone grafting may increase patient morbidity, costs, and rehabilitation time $e^{6,7}$. Studies have shown that management of unsatisfactory retention and stability of proathesis in patients with atrophied mandible can be done successfully by fabricating a fixed prosthesis with distal cantilevers ${ }^{8}$ or by 4 implants in the interforaminal areas (All on four concept) in which inclination of posterior implants was made to shorten cantilever length ${ }^{9}$. Another effective treatment approch to solve denture problems is the use of implant stabilized overdentures to avoid complications of vestibuloplasty and ridge augmentation ${ }^{10}$

Despite there is an evidence based knowledge that 2-implant overdentures is the minimum standard of care for the edentulous patients ${ }^{11}$, this type of rehabilitation relies mainly on mucosal support. The use of mandibular overdentures supported by 4 interforaminal implants have several merits including an increase in implant support, reduction of mucosal support ${ }^{12}$, optimization of stress distribution ${ }^{13,14}$, improvement of mandibular prosthesis stabilization and reduction of posterior mandibular bone resorption, probably because of reduction of denture movements in the posterior areas ${ }^{15}$. Implant supported mandibular overdentures are indicated in patients with high muscle attachments, prominent mylohyoid ridges, and knife-edged ridges or extreme gaggers ${ }^{16}$. It may also be indicated for patients with mandibular soreness and pain or sensitive mucosa, as they are supported by implants and reduce mucosal rubbing ${ }^{17}$. The implant supported overdenture showed several advantages compared to implant fixed prosthesis such as cost effectiveness, ability to be used with anatomic limitations such as advanced ridge atrophy that may compromise phonetics and aesthetics as loss of lip support, very long clinical crowns, or wide interproximal spaces. Implant overdentures are recommended with unfavorable arch relationships accompanied advanced resorption ${ }^{18}$. Also the hygiene of implant overdentures is very easy. ${ }^{19}$ Also, with short implant length to advanced atrophy, or if narrow ridges require reduced implant width (3.3 $\mathrm{mm})$, the use of 4 implants is recommended ${ }^{20}$. The high success rate of interforaminal implants used to support mandibular overdentures is well reported in long term studies ${ }^{21,22}$

Several attachments can be used to retain overdentures to the implants such as splinted (bar/clip) or non-splinted (stud and magnetic) attachments ${ }^{23}$. compared to splinted attachments, Locator attachment is a self-aligning, have internal and external flange retention with different values of retention (colour coded), ${ }^{24}$ provide increased retention and stability ${ }^{25}$, and can be used with decreased interarch space to reduce denture base fracture thanks to their low profile ${ }^{26}$. Moreover they provide limited lateral prosthesis movements due to presence of internal and external flanges which act as guide planes and therefore can be used in patients with resorbed ridges ${ }^{10,27}$. Locators also can be used with angulated individual implants up to $40^{\circ} 28$ without problems and can be easily replaced when retention is lost ${ }^{29}$. Being unsplinted, Locator also provide easier hygiene, fewer technical complications $^{24,30}$, can be used with pointed jaw which leaves insufficient tongue space for bar constructions $^{31}$ 
Patient-reported outcomes is becoming progressively noticeable in assessing the result of prosthodontic treatment ${ }^{32}$. The most commonly used perception method for evaluation of implant intervention in edentulous patients is oral healthrelated quality of life (OHRQoL). Patient satisfaction is another outcome that permits quantification of patients' opinion with respect to the result of prosthodontic treatment ${ }^{33}$. Accordingly, the aim of the present study was to evaluate patient satisfaction and oral health related quality of life (OHRQoL) for implant supported mandibular overdentures with locator attachments in patients with resorbed mandibular ridges.

\section{MATERIALS AND METHODS}

\section{Participants enrollment and study design}

Six participants ( 3 males and 3 females) with total maxillary and mandibular edentulism (mean age $=58 \pm 4.2$ years) who complained from lack of retention of old mandibular dentures due to ridge resorption were enrolled for this study from the patients regularly attend at the clinic of Prosthodontic department for follow up. The inclusion criteria include 1) mandibular ridge resorption with lack retention and stability of old mandibular dentures, 2) Sufficient bone quantity (class IV-VI according to Cawood and Howell ${ }^{34}$ and quality in the interforaminal area of the mandible to receive standard implants of at least $3.7 \times 11 \mathrm{~mm}$ as verified by perioperative cone beam computerized tomography. Exclusion criteria include: 1) General contraindications for surgical procedures such as patients with head and neck radio therapy, patients with bleeding disorders, hepatic patients, 2) Patients with metabolic disorders that affect osseointegration such as diabetes mellitus, and osteoporosis, 3) Long term immunosuppressive and corticosteroid drug therapy and smoking patient. All patients signed informed consents and the study plan was approved by the ethical committee of the faculty of dentistry, Mansoura University.

\section{Surgical and prosthetic procedures}

All participants received new maxillary and mandibular complete dentures (Control group, CD) constructed according to the conventional denture fabrication procedures ${ }^{35}$. Semi-anatomic acrylic resin teeth (Acrostone-Egypt) were arranged in bilateral balanced occlusion. The patients were informed to use the new dentures for 3 months to increase neuro muscular adaptation and necessary adjustments were made. Mandibular denture was duplicated to be used as radiographic template. Gutta perchae radiopaque markers are fixed to proposed implant position in the denture and cone beam CT (CBCT, i- CAT Vision ${ }^{\circledR}$, Imaging Sciences International, Hatfield, PA, USA) was performed.

For every participant, mid crestal incision was made and full thickness mucoperiosteal flap was raised. A mid line releasing incision was made if needed. Flattening of crestal bone was made using crestal bone osteotome when needed to provide at least $1 \mathrm{~mm}$ of one buccal and lingual to the implants. Four implants (Tiologic ${ }^{\circledR}$ Implants, Dentaurum, Ispringen, Germany) were inserted inter-foraminal area of the mandible using one stage non-submerged surgical approach with delayed implant loading. The osteotomy sites were prepared by drills of increasing size and made parallel to each other's using guide pins. During the implant insertion, a minimum $35 \mathrm{Ncm}$ value of insertion torque was achieved. Healing abutments were connected to the implants and the flap was closed around the haling abutments using interrupted sutures (fig 1). The denture was relieved above the healing abutments and relined with tissue conditioning material (COEComfort, GC America Inc., Chicago, IL, U.S.A). Post-operative medications include analgesics, antibiotics, mouth rinse for 2 weeks and antiinflammatory medication for 7 days.

After 3 months of osteointegration, healing abutments were removed and locator abutments (Tiologic $₫$ Implants, Dentaurum, Ispringen, Germany) 
were threaded to the implants at $25 \mathrm{Ncm}$ torque (fig 2 ). White blocking rings were placed over the abutments to relieve acrylic resin around the abutments and prevent excess acrylic resin to enter in peri-implant sulcus. Metal housing with black processing inserts were snapped on the locator abutments.

Using disclosing media, sufficient relieve was provided in the mandibular dentures over locator abutments to provide a space for Locators metal housing. Lingual vents were drilled in the lingual flange of the denture to allow escapement of excess acrylic resin material during the pickup procedure. The metal housings were picked to the tissue surface of the mandibular denture using autopolymerized acrylic resin while the participants close in retruded contact position. After polymerization of the acrylic

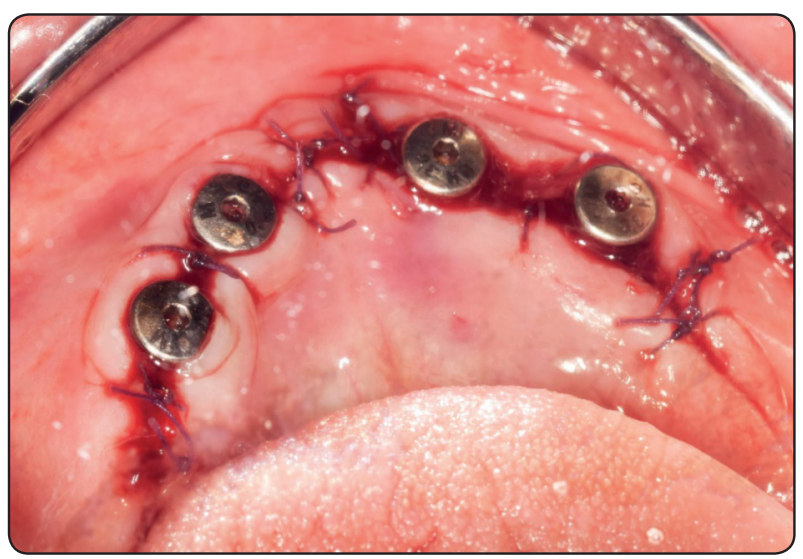

Fig. (1) Flap closure around healing abutment

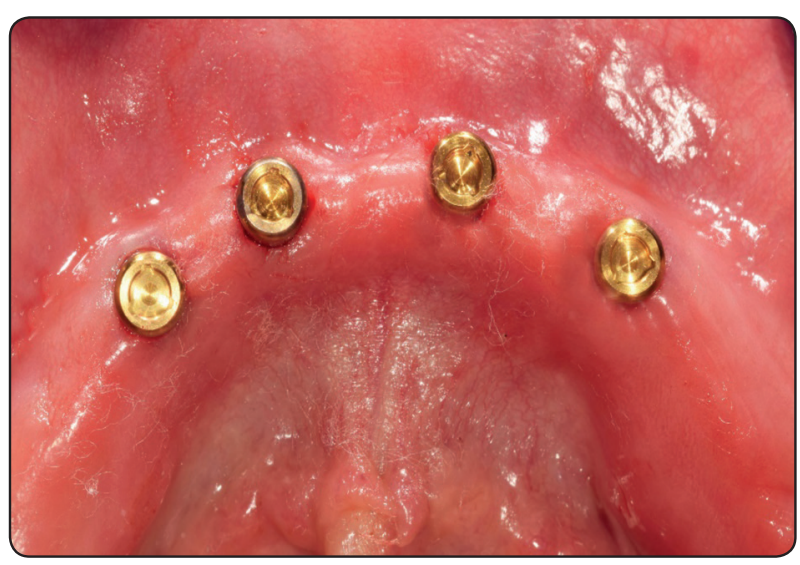

Fig. (2) Screwing of locator abutments to the implants resin, the mandibular denture was removed, excess acrylic resin around the abutments was removed to avoid unnecessary loading of the implants and the denture was finished and polished. Black processing inserts were removed using locator tool (fig 3) and replaced with blue nylon insert (extra light retention) and dentures delivered to the participants with emphasis on oral hygiene instructions and occlusion was refined.

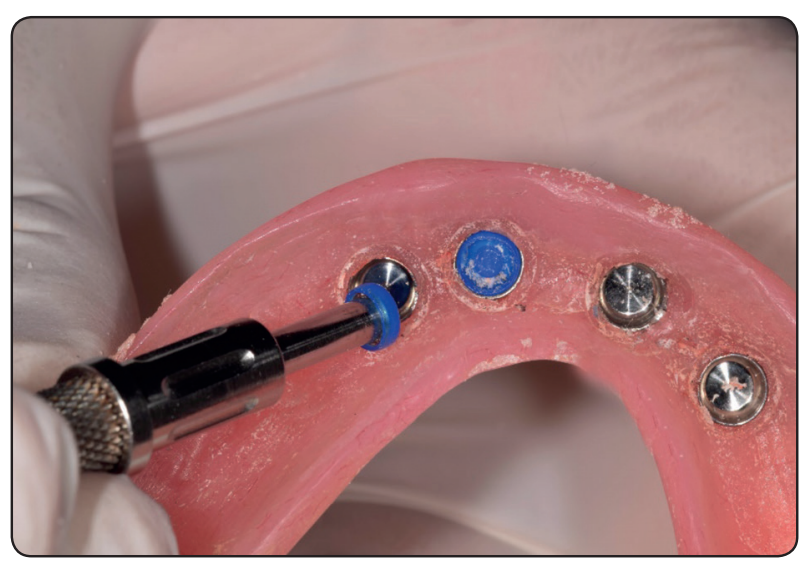

Fig. (3) Replacement of black processing insert with blue nylon inserts

\section{Evaluation of participant satisfaction and Oral Health Related Quality Profile:}

Measurements of patient satisfaction and oral health quality of life were performed 3 months after using conventional dentures and before implant placement (control, CD) and 3 months after using locator overdentures (test, OD) to enhance good muscle control.

Patient satisfaction was evaluated using a visual analogue scale Linkert ${ }^{36}$ in which each participant put a mark on $10 \mathrm{~cm}$ scale corresponding to his satisfaction of specific item of the questionnaire (included in table1). Higher VAS scores indicate high satisfaction and lower scores indicate low satisfaction. The questions of VAS include; general satisfaction of prosthesis, satisfaction of prosthesis 
compared to natural teeth, prosthesis retention, prosthesis stability, prosthesis occlusion, prosthesis cleaning, speech with prosthesis, appearance of prosthesis, chewing with prothesis, prosthesis handling, sensation that prosthesis is a part of the patient, feeling of embarrassment

Oral health related quality of life was measured using oral health impact profile (OHIP-14) questions $^{37}$. The OHIP contains 7 domains and each domain contain 2 questions (table 2). The domains are; functional limitation (pronouncing sounds, and sense of taste), physical pain (painful aching, and comfort on eating), psychologic discomfort (self-consciousness, and feeling tense), physical disability (unsatisfactory diet, and interrupting meals), psychologic disability (difficult to relax, and embarrassing), social disability (irritability with people, and difficulty in jobs), and handicap (life in general, and inability to function). Participant responses to each question of OHIP (included in table 2) were never (1), hardly ever (2), occasionally (3), fairly often (4) and very often (5). Lower scores indicated higher satisfaction, vice versa. All questionaires were translated and given in arabic to all participants.

\section{STATISTICAL ANALYSIS}

The data were explored for normality of distribution. The data was parametric and met the normal distribution. Descriptive statistics of VAS and OHIP were presented as mean and standard deviation. To compare patient satisfaction and oral health impact profile between the attachments, MannWhiteny test was utilized. The software package used for data analysis was SPSS ${ }^{\circledR}$ version 25 (SPSS Inc., Chicago, IL, USA). The level of significance was adjusted at $5 \%$.

\section{RESULTS}

Twenty four implants were inserted in six patients. Four patients need recontouring of alveolar crest before implant insertion. No implant failures occur and the success rate was $100 \%$. The short evaluation period (3 months) make all patients attend the regular follow up visits without dropouts.

Comparison of visual analogue scale (measured in millimeter) for control and test groups are presented in table 1 . There was no significant difference in prostheis cleaning, appearance and handling between test and control groups ( $\mathrm{p}>.05)$. Test group showed significant higher patient satisfaction with prosthesis compared to natural teeth, general patient satisfaction, satisfaction with prosthesis retention, satisfaction with prosthesis stability, satisfaction with prosthesis occlusion, satisfaction with prosthesis speech, comfort with prosthesis mastication, feeling that prosthesis is a part of patient, and lack of embarrassment due to prosthesis compared to control group.

Comparison of questions of oral health impact profile between groups is presented in table 2 . There was no significant difference in functional disorders (pronunciation of sound and sensation of taste) and social disability (difficulty in doing jobs) between test and control groups. Test group recorded significant lower OHIP-14 scores (ie higher patient satisfaction) with all other domains of OHIP compared to control group. Test group showed significant less pain or ache and more comfort on eating (physical pain domain), less elf-consciousness, and less sensation of tense (psychological disorder domain), more satisfaction with food and less interruption of meal (physical disability domain), more ability to relax and less embarrassing (psychological disability domain), less irritation with other (social disability domain) and more satisfaction with life generally and less difficulty in function well (handicap domain) than control group. 
TABLE (1) Comparison of visual analogue scale (measured in millimeter) for control and test groups

\begin{tabular}{|c|c|c|c|c|c|}
\hline & \multicolumn{2}{|c|}{$\begin{array}{l}\text { Conventional dentures } \\
\quad(\text { Control, CD) }\end{array}$} & \multicolumn{2}{|c|}{$\begin{array}{l}\text { Locator retained overdentures } \\
\text { (Test, OD) }\end{array}$} & \multirow[t]{2}{*}{$P$ value } \\
\hline & mean & Standard deviation & mean & Standard deviation & \\
\hline General satisfaction with prosthesis & 55 & 10.4 & 86 & 5.3 & $<.001 *$ \\
\hline $\begin{array}{l}\text { Satisfaction with prosthesis compared } \\
\text { to natural teeth }\end{array}$ & 46 & 7.9 & 80.2 & 9.8 & $<.001^{*}$ \\
\hline Prosthesis retention & 47.5 & 8.7 & 92.3 & 5.6 & $<.001 *$ \\
\hline Prosthesis stability & 49.7 & 10.1 & 94.2 & 6.7 & $<.001 *$ \\
\hline Prosthesis occlusion & 65.8 & 15.6 & 89 & 8.7 & $.003^{*}$ \\
\hline Prosthesis cleaning & 88.4 & 6.4 & 87.4 & 5.8 & .89 \\
\hline Prosthesis speech & 78.5 & 9.2 & 89 & 8.2 & $.001^{*}$ \\
\hline Comfort with Prosthesis mastication & 55.1 & 9.5 & 92 & 8.9 & $<.001^{*}$ \\
\hline Prosthesis Appearance & 85 & 9.4 & 87 & 7.9 & .94 \\
\hline Ease of handling of Prosthesis & 90 & 5.8 & 92 & 6.6 & .85 \\
\hline Prosthesis apart of you & 65.7 & 8.8 & 92.2 & 7.5 & $<.001 *$ \\
\hline Embarrassment due to prosthesis & 66.4 & 7.9 & 90.6 & 7.3 & $<.001^{*}$ \\
\hline
\end{tabular}

*P is significant at $.05 \%$

TABLE (2) Comparison of Oral health impact profile for control and test groups

$\begin{array}{llccccc} & & \begin{array}{c}\text { Conventional dentures } \\ \text { (Control, CD) }\end{array} & \begin{array}{c}\text { Locator retained overdentures } \\ \text { (Test, OD) }\end{array} & \text { P value } \\ \text { Domain } & \text { Question } & \text { Mean } & \text { Standard deviation } & \text { Mean } & \text { Standard deviation } & \\ \text { Function } & \text { Pronunciation of sound } & 2.90 & .68 & 2.8 & .81 & .15 \\ \text { disorders } & \text { Sensation of taste } & 2.60 & .60 & 2.40 & .62 & .35 \\ \text { Physical pain } & \text { Pain or ache } & 3.90 & .87 & 1.80 & .81 & <.001^{*} \\ & \text { Comfort on eating } & 4.01 & .91 & 1.70 & .64 & <.001^{*} \\ \text { Psychological } & \text { Self-consciousness } & 3.80 & .69 & 2.30 & .57 & .002^{*} \\ \text { disorders } & \text { Sensation of tense } & 3.90 & .89 & 2.1 & .64 & .003^{*} \\ \text { Physical disability } & \text { Unsatisfaction with food } & 3.89 & .68 & 1.89 & .51 & <.001^{*} \\ & \text { Interruption of meal } & 4.3 & .95 & 2.06 & .77 & .001^{*} \\ \text { Psychological } & \text { Unable to relax } & 3.90 & .89 & 1.97 & .67 & <.001^{*} \\ \text { disability } & \text { Embarrassed } & 4.01 & .69 & 2.20 & .67 & <.001^{*} \\ \text { Social disability } & \text { Irritation with others } & 3.80 & .70 & 2.70 & .57 & .008^{*} \\ & \text { Difficult doing job } & 2.91 & .64 & 3.00 & .47 & .19 \\ \text { Handicapping } & \text { Life generally } & 3.50 & .72 & 2.00 & .62 & .004^{*} \\ & \text { Difficulty in function well } & 4.80 & .73 & 1.84 & .71 & <.001^{*}\end{array}$

${ }^{*} P$ is significant at $.05 \%$ 


\section{DISCUSSION}

The design of the present study was cross-over. This mean that every patient act as control of himself (within patient investigation). Therefore, each patient receives conventional dentures first and after measurement of VAS and OHIP, implants were inserted and dentures were connected to the implants to become overdentures. This study eliminates the between-patient variation regarding age, sex, muscle power, neuromuscular control, amount of ridge atrophy, amount of remaining bone and other anatomical factors that may affect patient satisfaction. Since the same denture was used for both test and control group, this standardize prosthetic factors as denture extension and peripheries, occlusion, denture contour and lip support, vertical dimension, ... etc. that also may affect patient satisfaction. Furthermore, this design allow the use of small patient sample and give adequate power in the results compared to separate groups ${ }^{38}$. Satisfaction with old denture was not measured since all participants were already unsatisfied with existing dentures. It was reported in the literature that the new dentures alone can improve patient satisfaction and quality of life ${ }^{39}$. Therefore, new conventional denture was provided for all patient to act as a control.

Reviewing the literature, studies evaluated patient satisfaction and oral health related quality of life with implant supported locator retained overdentures in patients with atrophied mandibles are scares ${ }^{12,40}$. di Torresanto et al ${ }^{40}$ evaluated patient satisfaction (using visual analogue scale) with locator retained mandibular overdentures supported by 4 implants inserted with flapless surgical approach. The authors found high patient satisfaction. However, this study did not include control (CD group) and not included subjects with resorbed ridges Zou et al. ${ }^{41}$ investigated telescopic, bar, and locator attachments for maxillary 4 implant-supported overdentures and found that locator attachments produced superior clinical results in terms of peri-implant hygiene and prosthetic complications but no difference in patient satisfaction between attachments were noted. Also,
Cordaro et al. ${ }^{12}$ showed no significant difference in patient satisfaction between locator and milled bar attachments used for mandibular implant overdentures supported by 4 implants. However, the aforementioned studies were in a separate group design (not within patient) and did not include control (conventional denture) group.

Test group showed significant higher patient satisfaction with prosthesis compared to natural teeth, general patient satisfaction, satisfaction with prosthesis retention, satisfaction with prosthesis stability and less irritation with other (social disability domain of OHIP) than control group. Moreover, test group showed better life in general and less difficulty in function well (handicap domain of OHIP). This could be attributed to the increased support, stability and retention of the complete denture following insertion of the implants and connection of the denture to the implants by locator attachments. The latter is a key element in removable prosthodontics where there is strong evidence of patient preference for the overdenture attachment with superior retention. ${ }^{42}$ This observation was expected and is in line with several studies ${ }^{4,5,43-49}$. In the conventional denture group, the elevated floor of the mouth and elevated muscle attachments due to mandibular ridge resorption make the dentures unstable and lacks retention ${ }^{20}$. This caused traumatization of delicate non keratinized mucosa supporting the dentures leading to reduced patient satisfaction. In agreement with our observation, another study ${ }^{50}$ showed an improved effect of implant overdentures compared to traditional dentures regarding patient satisfaction, especially for especially for subjects who cannot tolerate conventional dentures.

In this study, test group demonestrated increased satisfaction with prosthesis speech, feeling that prosthesis is a part of patient, and lack of embarrassment (VAS) due to prosthesis compared to control group. Test group also showed more ability to relax and less embarrassing (psychological disability domain of OHIP), less self-consciousness, and less sensation of tense (psychological disorder 
domain of OHIP). The improvement speech and lack of embarrassing could be attributed to the increased stability of the prosthesis as Locator attachments have internal and external frictional flanges that act as guide plane and resist lateral and antro-posterior movements of the denture in patients with atrophied ridges. The increased retention and stability of the prosthesis together with increased muscle adaptation makes the patients feeling that the prosthesis is a part of them. Furthermore, the reduced height of the locator attachment makes the patients did not sense attachment projection. They are more relaxed and less embarrassed during speech due to due to the contraction of the mentalis, buccinators, or mylohyoid muscles which may lift the denture off the soft tissue. As a consequence, the teeth may touch during speech and elect clicking noises. The retentive implant overdenture remains in place during mandibular movement. The tongue and peri-oral musculature may resume a more normal position because they are not required to limit mandibular denture movement ${ }^{51}$. In line with these findings, several studies showed that $45 \%$ of patients dissatisfied with regard speech and appearance in public ${ }^{52,53}$

The increased satisfaction with implant overdentures regarding occlusion and mastication (VAS), less pain or ache and more comfort on eating (physical pain domain of OHIP) and more satisfaction with food and less interruption of meal (physical disability domain of OHIP) than control group is in line with findings of Awad et al. ${ }^{5}$ who reported that implant overdentures improves chewing foods with different textures. This could be attributed to the increased stability and retention of the prosthesis which produce comfort, improve occlusal forces and biting forces and enhance the patient ability of mastication ${ }^{54}$. Implant overdentures also improve oral perception, function, and psychological aspects $^{48,55}$. In addition, the support provided by the implants reduced the mucosal compression during mastication. On the other hand the lack of stability of the denture caused by ridge resorption causes pain during mastication and biting, reduces muscle activity and masticatory function ${ }^{38}$. The compression of the soft tissue under the complete dentures during mastication and biting limits muscle activity and affect masticatory effeciency ${ }^{32}$. In line with our finding, Awad et al. ${ }^{43}$ showed improved OHRQoL with implant supported overdentures compared to traditional dentures.

The limitations of this study included the small patient number. Moreover, a wash period is recommended in future study between the conventional dentures and implant overdentures to reduce the carry-over effects on the patient satisfaction measurements.

\section{CONCLUSION}

Implant supported mandibular overdentures with locator attachments are recommended for patients with atrophied mandibular ridges as they significantly improve patient satisfaction and quality of life compared to conventional dentures.

\section{REFERENCES}

1. Cakarer S, Can T, Yaltirik M, Keskin C. Complications associated with the ball, bar and Locator attachments for implant-supported overdentures. Med Oral Patol Oral Cir Bucal. 2011;16:e953-9.

2. Santagata M, Guariniello L, D'Andrea A, Tartaro G. A modified crestal ridge expansion technique for immediate placement of implants: a report of three cases. J Oral Implantol. 2008;34:319-24.

3. Doundoulakis JH, Eckert SE, Lindquist CC, Jeffcoat MK. The implant-supported overdenture as an alternative to the complete mandibular denture. J Am Dent Assoc. 2003;134:1455-8.

4. Allen PF, McMillan AS, Walshaw D. A patient-based assessment of implant-stabilized and conventional complete dentures. J Prosthet Dent. 2001;85:141-7.

5. Awad MA, Lund JP, Shapiro SH, Locker D, Klemetti E, Chehade A, et al. Oral health status and treatment satisfaction with mandibular implant overdentures and conventional dentures: a randomized clinical trial in a senior population. Int J Prosthodont. 2003;16:390-6. 
6. Stellingsma C, Vissink A, Meijer HJ, Kuiper C, Raghoebar GM. Implantology and the severely resorbed edentulous mandible. Crit Rev Oral Biol Med. 2004;15:240-8.

7. Stellingsma K, Raghoebar GM, Meijer HJ, Stegenga B. The extremely resorbed mandible: a comparative prospective study of 2-year results with 3 treatment strategies. Int J Oral Maxillofac Implants. 2004;19:563-77.

8. Capelli M, Zuffetti F, Del Fabbro M, Testori T. Immediate rehabilitation of the completely edentulous jaw with fixed prostheses supported by either upright or tilted implants: a multicenter clinical study. Int J Oral Maxillofac Implants. 2007;22:639-44.

9. Malo Bo R, Nobre M. Concept with Brlaanemark System Itextregistered Implants for Completely Edentulous Mandibles : A Retrospective Clinical Study. Implant Dent. 2003:2-9.

10. ELsyad MA, Denewar BA, Elsaih EA. Clinical and Radiographic Evaluation of Bar, Telescopic, and Locator Attachments for Implant-Stabilized Overdentures in Patients with Mandibular Atrophied Ridges: A Randomized Controlled Clinical Trial. The International journal of oral \& maxillofacial implants. 2018;33:1103-11.

11. Thomason JM, Feine J, Exley C, Moynihan P, Muller F, Naert I, et al. Mandibular two implant-supported overdentures as the first choice standard of care for edentulous patients--the York Consensus Statement. Br Dent J. 2009; 207:185-6.

12. Cordaro L, di Torresanto VM, Petricevic N, Jornet PR, Torsello F. Single unit attachments improve peri-implant soft tissue conditions in mandibular overdentures supported by four implants. Clin Oral Implants Res. 2013;24:536-42.

13. el-Sheikh AM, Hobkirk JA. Force transmission in barretained implant-stabilised mandibular over-dentures: an in-vitro study. Eur J Prosthodont Restor Dent. 2002; 10:173-8.

14. Wright PS, Watson RM. Effect of prefabricated bar design with implant-stabilized prostheses on ridge resorption: a clinical report. Int J Oral Maxillofac Implants. 1998;13:7781 .

15. de Jong MH, Wright PS, Meijer HJ, Tymstra N. Posterior mandibular residual ridge resorption in patients with overdentures supported by two or four endosseous implants in a 10-year prospective comparative study. Int J Oral Maxillofac Implants. 2010;25:1168-74.
16. Wismeijer D, van Waas MA, Kalk W. Factors to consider in selecting an occlusal concept for patients with implants in the edentulous mandible. J Prosthet Dent. 1995;74:380-4.

17. Batenburg RH, Raghoebar GM, Van Oort RP, Heijdenrijk K, Boering G. Mandibular overdentures supported by two or four endosteal implants. A prospective, comparative study. Int J Oral Maxillofac Surg. 1998;27:435-9.

18. Ekfeldt A, Johansson LA, Isaksson S. Implant-supported overdenture therapy: a retrospective study. Int J Prosthodont. 1997; 10:366-74.

19. Martinez-Lage-Azorin JF, Segura-Andres G, Faus-Lopez J, Agustin-Panadero R. Rehabilitation with implant-supported overdentures in total edentulous patients: A review. J Clin Exp Dent. 2013;5:e267-72.

20. Mericske-Stern RD, Taylor TD, Belser U. Management of the edentulous patient. Clin Oral Implants Res. 2000;11 Suppl 1:108-25.

21. Batenburg RH, Meijer HJ, Raghoebar GM, Van Oort RP, Boering G. Mandibular overdentures supported by two Branemark, IMZ or ITI implants. A prospective comparative preliminary study: one-year results. Clin Oral Implants Res. 1998;9:374-83.

22. Davis DM, Rogers JO, Packer ME. The extent of maintenance required by implant-retained mandibular overdentures: a 3-year report. Int J Oral Maxillofac Implants. 1996;11:767-74.

23. Sadowsky SJ. Treatment considerations for maxillary implant overdentures: a systematic review. J Prosthet Dent. 2007;97:340-8.

24. Trakas T, Michalakis K, Kang K, Hirayama H. Attachment systems for implant retained overdentures: a literature review. Implant Dent. 2006;15:24-34.

25. Chung KH, Chung CY, Cagna DR, Cronin RJ, Jr. Retention characteristics of attachment systems for implant overdentures. J Prosthodont. 2004;13:221-6.

26. ELsyad MA, Errabti HM, Mustafa AZ. Mandibular Denture Base Deformation with Locator and Ball Attachments of Implant-Retained Overdentures. J Prosthodont. 2016;25:656-64.

27. Yang TC, Maeda Y, Gonda T, Kotecha S. Attachment systems for implant overdenture: influence of implant inclination on retentive and lateral forces. Clin Oral Implants Res. 2011;22:1315-9. 
28. Nguyen CT, Masri R, Driscoll CF, Romberg E. The effect of denture cleansing solutions on the retention of pink Locator attachments: an in vitro study. J Prosthodont. 2010;19:226-30.

29. Kleis WK, Kammerer PW, Hartmann S, Al-Nawas B, Wagner W. A comparison of three different attachment systems for mandibular two-implant overdentures: one-year report. Clin Implant Dent Relat Res. 2010;12:209-18.

30. Alsabeeha NH, Payne AG, Swain MV. Attachment systems for mandibular two-implant overdentures: a review of in vitro investigations on retention and wear features. Int J Prosthodont. 2009;22:429-40.

31. Spiekermann H. Implantology. In: Rateitschak, K.H. \& Wolf, H.F., eds. Color Atlas of Dental Medicine. New York: Thieme Medical Publishers. 1995:164.

32. ELsyad M, Elgamal M, Askar O, Al-Tonbary G. Patient satisfaction and oral health-related quality of life (OHRQoL) of conventional denture, fixed prosthesis and milled bar overdenture for All-on-4 implant rehabilitation. A crossover study. Clin Oral Implants Res. 2019; 30:1107-17.

33. Khalid T, Yunus N, Ibrahim N, Elkezza A, Masood M. Patient-reported outcome and its association with attachment type and bone volume in mandibular implant overdenture. Clin Oral Implants Res. 2017;28:535-42.

34. Cawood JI, Howell RA. A classification of the edentulous jaws. Int J Oral Maxillofac Surg. 1988;17:232-6.

35. Zarb G, Bolender C, Eckert S, Jacob R, Fenton A, Mericske-Stern R. Prosthodontic treatment for edentulous patients: complete dentures and implant-supported prostheses. 12th ed St Louis: Mosby. 2003:p. 211-425.

36. Awad MA, Feine JS. Measuring patient satisfaction with mandibular prostheses. Community Dent Oral Epidemiol. 1998;26:400-5.

37. Slade GD, Spencer AJ. Development and evaluation of the Oral Health Impact Profile. Community Dent Health. 1994;11:3-11.

38. Elsyad MA, Khairallah AS. Chewing efficiency and maximum bite force with different attachment systems of implant overdentures: a crossover study. Clin Oral Implants Res. 2017;28:677-82.

39. Allen PF, McMillan AS. A review of the functional and psychosocial outcomes of edentulousness treated with complete replacement dentures. J Can Dent Assoc. 2003; 69:662.

40. di Torresanto VM, Milinkovic I, Torsello F, Cordaro L. Computer-assisted flapless implant surgery in edentulous elderly patients: a 2-year follow up. Quintessence Int. 2014;45:419-29.

41. Zou D, Wu Y, Huang W, Wang F, Wang S, Zhang Z, et al. A 3-year prospective clinical study of telescopic crown, bar, and locator attachments for removable four implantsupported maxillary overdentures. Int J Prosthodont. 2013; 26:566-73.

42. Burns DR, Unger JW, Elswick RK, Jr., Giglio JA. Prospective clinical evaluation of mandibular implant overdentures: Part II--Patient satisfaction and preference. J Prosthet Dent. 1995;73:364-9.

43. Awad MA, Locker D, Korner-Bitensky N, Feine JS. Measuring the effect of intra-oral implant rehabilitation on health-related quality of life in a randomized controlled clinical trial. J Dent Res. 2000;79:1659-63.

44. Awad MA, Lund JP, Dufresne E, Feine JS. Comparing the efficacy of mandibular implant-retained overdentures and conventional dentures among middle-aged edentulous patients: satisfaction and functional assessment. Int J Prosthodont. 2003;16:117-22.

45. Allen F, Locker D. A modified short version of the oral health impact profile for assessing health-related quality of life in edentulous adults. Int J Prosthodont. 2002; 15:446-50.

46. Heydecke G, Locker D, Awad MA, Lund JP, Feine JS. Oral and general health-related quality of life with conventional and implant dentures. Community Dent Oral Epidemiol. 2003;31:161-8.

47. Naert I, Alsaadi G, Quirynen M. Prosthetic aspects and patient satisfaction with two-implant-retained mandibular overdentures: a 10-year randomized clinical study. Int J Prosthodont. 2004; 17:401-10.

48. Bakke M, Holm B, Gotfredsen K. Masticatory function and patient satisfaction with implant-supported mandibular overdentures: a prospective 5-year study. Int J Prosthodont. 2002; 15:575-81.

49. Yunus N, Saub R, Taiyeb Ali TB, Salleh NM, Baig MR. Patient-based and clinical outcomes of implant telescopic attachment-retained mandibular overdentures: a 1-year longitudinal prospective study. Int J Oral Maxillofac Implants. 2014;29:1149-56. 
50. Sharka R, Abed H, Hector M. Oral health-related quality of life and satisfaction of edentulous patients using conventional complete dentures and implantretained overdentures: An umbrella systematic review. Gerodontology. 2019.

51. Misch C. Contemporary implant dentistry. $3^{\text {rd }}$ ed. Mosby. 2008:P.9-10.

52. van Waas MA. Determinants of dissatisfaction with dentures: a multiple regression analysis. J Prosthet Dent. 1990;64:569-72.
53. Peltola MK, Raustia AM, Salonen MA. Effect of complete denture renewal on oral health--a survey of 42 patients. J Oral Rehabil. 1997;24:419-25.

54. van Kampen FM, van der Bilt A, Cune MS, FontijnTekamp FA, Bosman F. Masticatory function with implantsupported overdentures. J Dent Res. 2004;83:708-11.

55. Karkazis H. EMG activity of the masseter muscle in implant supported overdenture wearers during chewing of hard and soft food. J Oral Rehabil. 2002;29:986-91. 